\title{
PROGRAM PELESTARIAN DAN NILAI EKONOMIS RUMAH ADAT MASYARAKAT OSING
}

\author{
Nofi Nurman \\ Universitas Islam Negeri Sulthan Thaha Saifuddin Jambi \\ nofinurman@uinjambi.ac.id
}

\begin{abstract}
Abstrak. Pembangunan desa merupakan bagian dari pembangunan nasional. Pasca reformasi, desa diberikan ruang untuk mengelola rumah tangganya sendiri berdasarkan karakteristik desa itu sendiri. Undang-Undang Nomor 6 Tahun 2014 tentang Desa (UU Desa) telah membuka sebuah era baru dalam pembangunan di Indonesia. Bukan hanya dikarenakan penduduk Indonesia terkonsentrasi di daerah pedesaan, melainkan desa-desa di Indonesia memiliki tantanan kehidupan yang telah lama dipegang teguh oleh masyarakatnya, salah satunya Desa Kemiren, desa wisata yang ada di Kabupaten Banyuwangi sebagaimana tertuang dalam Rencana Pembangunan Jangka Menengah Daerah (RPJMD) Kabupaten Banyuwangi tahun 2010-2015 yakni, "mewujudkan Banyuwangi sebagai daerah tujuan wisata nasional yang berbasis kebudayaan dan potensi alam serta lingkungan”. Selain menjaga kelestarian budaya setempat, program pembangunan desa yang berbasis kearifan lokal juga memberikan dampak positif dalam menunjang pembangunan ekonomi masyarakat di Desa Kemiren. Ada berbagai potensi dan ciri khas yang dimiliki masing-masing desa, antara lain: flora, fauna, rumah adat, pemandangan alam, iklim, makanan tradisional, kerajinan tangan, seni tradisional, dan sebagainya.Tentunya semua potensi itu tidak akan mengalami perkembangan tanpa adanya partisipatif langsung dari masyarakat setempat.
\end{abstract}

Kata kunci: Pembangunan, Rumah Adat, Pelestarian

\section{PENDAHULUAN}

Kemiren adalah nama sebuah desa di Bayuwangi dimana desa tersebut dinobatkan sebagai desa adat oleh pemerintah Kabupaten Banyuwangi. Memiliki luas 177.052 Ha dengan penduduk 2.562 Jiwa (2017). Nama Kemiren sendiri merupakan kepanjangan dari Kemronyok Mikul Rencana Nyata (bersama-sama dan gotong royong) yang dicetus oleh POKDARWIS atau kelompok sadar wisata Desa Kemiren. Ada juga arti lainnya bahwa kemiren berasal dari nama Kemirian (dikarenakan banyak pohon kemiri, duren dan aren) yang kemudian masyarakat menyebut daerah tersebut Kemiren hingga saat ini. 
Masyarakat Kemiren dikenal dengan sebutan masyarakat suku Osing, yang merupakan suku asli Banyuwangi yang mayoritas tinggal di Desa Kemiren. Orangorang Osing adalah masyarakat Blambangan yang tersisa. Keturunan kerajaan Blambangan ini berbeda dari masyarakat Jawa, Mataram dan Bali lainnya dilihat dari adat istiadat budaya maupun bahasa.

Setelah ditetapkan sebagai desa wisata, Desa Kemiren telah banyak menarik para wisatawan baik domestik maupun mancanegara dan bahkan tidak sedikit dari para peneliti dalam maupun luar negeri melakukan penelitian tentang masyarakat suku Osing di Desa Kemiren yang membuat Desa Kemiren tidak hanya dikenal di Indonesia melainkan juga di mancanegara sebagai desa wisata dengan masyarakat suku Osingnya. Hal tersebut membuktikan bahwa Desa Kemiren memiliki potensi yang besar untuk dikembangkan.

Untuk melaukan pengembangan terhadap potensi-potensi yang dimiliki desa tentu tidaklah mudah, perlu pengkajian atau analisis mendalam agar perencanaan terhadap pembangunan desa tepat sasaran dan hasilnya akan memberikan dampak kesejahteraan bagi masyarakatnya. Sebagaimana yang diatur di dalam Peraturan Menteri Dalam Negeri No. 114 Tahun 2014, tentang pedoman pembangunan desa, disebutkan bahwa perencanaan pembangunan desa adalah proses tahapan kegiatan yang diselenggarakan oleh pemerintah desa dengan melibatkan Badan Permusyawaratan Desa dan unsur masyarakat secara partisipatif guna pemanfaatan dan pengalokasian sumber daya desa dalam rangka pencapai tujuan pembangunan desa. Lebih lanjut, pelibatan masyarakata atau partisipatif adalah suatu sistem pengelolaan pembangunan di desa dan kawasan pedesaan dan dikoordinasikan oleh Kepala Desa dengan mengedepankan kebersamaan, kekeluargaan dan kegotongroyongan. Oleh sebab itu, sebagus apapun perencanaan dan program pembangunan di pedesaan tanpa ada pelibatan masyarakat di dalamnya, maka pemabangunan belum mengartikulasikan sebuah pembangunan yang didasari dari semangat kegotongroyongan. 
Di Desa Wisata Osing, pengembangan potensi wisata cenderung belum optimal karena kebijakan pengembangan wisata, terutama wisata budaya Osing masih mengandalkan pemerintah sebagai aktor dominan, pelibatan tokoh di luar pemerintah terutama masyarakat masih dinilai kurang. ${ }^{1}$

Untuk sebuah desa wisata budaya, pendekatan kearifan lokal sudah menjadi pilihan dalam pendekatan program pembangunan. Dari pendekatan kearifan lokal, kegiatan pembangunan dilakukan untuk membangun, memelihara, serta pengadaan sarana dan prasarana dibidang kesenian dan kebudayaan sehingga tradisi yang melekat dimasyarakat dapat teroptimalkan potensinya. Dengan kata lain, kebijakan kepariwisataan harus mampu mendorong proses distribusi dan redistribusi sumber daya pariwisata yang didasarkan pada prinsip-prinsip yang adil dan demokratis. Mekanisme pengelolaan yang didominasi oleh otoritas negara jelas tidak menjadi jaminan tunggal bagi bekerjanya prinsip-prinsip ketata pemerintahan yang demokratis, yaitu pariwisata haruslah dilihat sebagai sumberdaya lokal sehingga pengelolaannya didasarkan pada kepentingan dan kemampuan masyarakat lokal dalam menyediakan tenaga dan modal sosial yang lain. ${ }^{2}$

Berangkat dari perspektif bahwa desa wisata yang ada merupakan perkembangan dari kegiatan turun temurun dari sebuah tradisi, maka sudah semestinya program pembangunan harus didasari dari masyarakat, milik masyarakat dan untuk masyarakat desa. Masyarakat memiliki nilai-nilai budaya yang luhur: gotong royong, ramah, alam lingkungan, seni, perlengkapan termasuk arsitektur dan nilai lainnya yang syarat akan sebuah tradisi.

Program pembangunan dari pemerintah daerah hingga pemerintah desa adalah berbasis kearifan lokal, seperti yang diungkapkan oleh kepala Desa Kemiren, bahwa pembangunan desa haruslah mendukung pengembangan dan pelestarian kebudayaan masyarakat Osing. Salah satu program pembangunan berbasis kearifan

1 Anastasia Murdyastuti, Kebijakan Akselerasi Pengembangan Kawasan Wisata Using Berbasis Democratic Governance (Studi Kabupaten Bayuwangi, 2013).

${ }^{2}$ Brohman, J, "New Direction in Tourism for Third World Development. Annals of Tourism Research". Vol. 23 No. 1,(1996), hlm. 48-70. 
lokal di Desa Kemiren adalah pelestarian rumah adat masyarakat Osing. Lebih lanjut, tulisan ini akan memfokuskan pada program pembangunan pelestarian rumah adat, dimana rumah adat merupakan salah satu simbol kearifan lokal yang ada di Desa Kemiren dan didukung penuh oleh pemerintah dalam pelaksanaan program tersebut. ${ }^{3}$

\section{Pandangan Hidup dari Sebuah Konstruksi Bangunan}

Seperti halnya suku lainnya di Indonesia, masyarakat Osing merupakan masyarakat yang sangat kental terhadap tradisi leluhur. Nuansa itu bahkan sudah terasa sangat jelas ketika memasuki gerbang Desa Kemiren dimana terdapat miniatur rumah adat masyarakat suku Osing. Bahkan bukan hanya sekedar miniatur yang terpajang, melainkan sebuah harapan yang akan diwujudkan dalam sebuah program pembangunan yang berbasis kearifan lokal, yakni pelestarian rumah adat masyarakat suku Osing.

Rumah adat merupakan sebuah seni arsitektur yang memiliki ciri khas tertentu. Rumah adat merupakan representasi kebudayaan yang paling tinggi dalam sebuah komunitas suku/masyarakat. Rumah adat masyarakat Osing merupakan rumah asli atau rumah tradisional daerah Banyuwangi. Rumah adat masyarakat Osing telah dibangun dari generasi ke generasi oleh masyarakat Osing yang ada di Banyuwangi. Rumah adat Osing mengandung makna yang luas, tidak hanya makna kegunaan tetapi mempunyai fungsi sosial dan makna budaya. ${ }^{4}$

Rumah adat masyarakat Osing dibagi menjadi tiga model konstruksi, yaitu model tikel balung dengan empat atap rumah, model baresan dengan tiga atap rumah dan model cerocongan dengan dua atap rumah. Untuk bagian dalam rumah terdiri atas bale (ruang tamu), jerumah (kamar) dan pawon (dapur), sedangkan bagian luar terdiri atas amper (teras) dan ampok (teras samping kanan-kiri). Ketiga model rumah tersebut menggambarkan filosofi awal proses dalam berumah tangga. Model

\footnotetext{
3 Wawancara dengan Kepala Desa Kemiren tanggal 29 November 2016 di Kantor Desa.

4 Isa Ma'rufi, “ Rumah Adat Using: Pembacaan Dari Sudut Pandang Rumah Sehat”. Dalam Novi Anoegrajekti,dkk, Kebudayaan Using:Konstruksi, Identitas dan Pengembangannya, (Ombak, 2016), hal. 340.
} 
Cerocongan menggambarkan penghuninya merupakan pasangan suami isteri muda yang baru menikah dan dari sisi kemapanan belum maksimal. Model Baresan menggambarkan keluarga sudah lumayan mapan dan secara struktur keluarga sudah memiliki beberapa anak. Model tikel balung menggambarkan keluarga bahagia yang sangat mapan dan sejahtera.

Secara umum rumah sebagai tempat untuk melepaskan lelah, bergaul, membina rasa kekeluargaan antar anggota keluarga, berlindung, menyimpan barang berharga dan sebagai lambang status sosial. ${ }^{5}$ Dalam artian khusus, rumah adat merupakan bangunan yang memiliki ciri khas, digunakan untuk tempat hunian oleh suatu komunitas masyarakat tertentu. Rumah merupakan representasi kebudayaan yang paling tinggi dalam sebuah komunitas suku/masyarakat. Kesadaran akan artian khusus inilah yang membuat masyarkat Osing tersadar akan pentingnya pelestarian rumah adat Osing. Seperti dikemukakan oleh kepala adat Desa Kemiren:

" untuk membuat rumah ada perbitungan dan ukuran sendiri lalu dipotong, rumah adat ada kaitannya dg rumah tangga, jika ada anak laiki-laki yang sudah menikah dikasih rumah adat oleh orang tua laki-laki. Mengapa harus laki-laki? Karen laki-laki sebagai pengayom terhadap anak dan istri. Banyak filosofi dari rumah adat ini, diantaranya tiang ada empat yang berarti besan sama besan berembuk, bermusyawarah utuk merencanakan sebuah pernikahan anak. Setelah bersepakat, masing-masing orang tua memberikan wejangan kepada anak. Diatas konstruksi ada jaitan yang mengartikan sebuah penyatuan sedangkan lambyang merupakan sebuah keteguhan hati atau ketidakbimbangan dalam berumah tangga dan bukan karena iming-iming harta dan lainnya. Di atas konstruksi juga terdapat plari yang artinya jangan tinggal pluri, merupakan pesan orang tua dimana apa yang sudah diwariskan oleh orang tua jangan dilupakan, misalnya, jika sudah berumah tangga jangan ander, ander itu ojo gemeter, artinya jangan menuruti tingkah laku masih bujangan setelah berumah tangga". ${ }^{6}$

5 Ibid 341.

6 Wawancara dengan Tokoh Adat Desa Kemiren tanggal 4 Desember 2016. 
Dari pernyataan ketua adat tersebut, kita bisa memahami bahwa rumah adat yang secara fisik merupakan benda mati namun seolah hidup dengan nilainilai kehidupan yang terkandung pada setiap unsur bangunan tersebut. Sejatinya proses-proses pembangunan sudah dimulai dilukgnkangan terkecil bagi masyarakat Osing, yaitu dilingkungan keluarga. Bangunan (rumah adat) yang mereka tempati sebagai pengingat dalam berperilaku menjalankan kehidupan berumah tangga.

Itu artinya, proses pembangunan keluarga sudah dimulai oleh mayoritas masyarakat adat di tanah air terkhusus dalam hal ini masyarakat Osing. Pemerintah dalam peraturan No. 87 Tahun 2014 tentang Perkembangan Kependudukan dan Pembangunan Keluarga, Keluarga Berencana dan Sistem Informasi Keluarga juga menaruh perhatian akan pembangunan keluarga. Tentunya dengan adanya peraturan tersebut semakin menguatkan posisi nilainilai budaya.

Namun sangat disayangkan, nilai luhur yang terkandung dalam arsitektur tersebut tidak banyak yang memahaminya, terutama para generasi muda saat ini. Di masyarakat Osing, pemahaman akan nilai luhur yang terkandung pada bangunan rumah adat sudah mulai memudar, terutama bagi generasi muda, tentunya hal tersebut sudah harus menjadi perhatian bagi orang tua dan bahkan pemangku adat agar nilai-nilai budaya bisa diwariskan ke generasi muda terutama nilai luhur yang ada pada filosofis sebuah bangunan rumah.

\section{Pelestarian Rumah Adat Bagi Masyarakat Osing}

Jika kita membaca teori kebutuhan Maslow, maka posisi rumah sebagai tempat tinggal berada pada posisi paling dasar (Physiological Needs) pada setiap orang, artinya kebutuhan dasar adalah kebutuhan yang tidak boleh jika tidak terpenuhi. Salah satu upaya dalam hal pemenuhan kebutuhan tersebut adalah melalui proses pembangunan. Namun perlu disadari, tidak semua model pembangunan dapat 
mengakomodir dari setiap tujuan-tujuan pembangunan. Pendekatan pembangunan pada masa orde baru misalnya, pembangunan lebih bersifat sentralistik. Itu artinya kewenangan pembangunan sepenuhnya berada pada pemerintah pusat dan pemerintah daerah tidak dilibatkan. Akibatnya, terjadi kelambatan pembangunan dikarenkan proses birokrasi yang terlalu panjang dan bahkan proses pembangunan tidak dapat menyentuh hakikat dari pembangunan, yakni membangun masyarakat itu sendiri sesuai dengan karakteristik kewilayahannya. Bentuk reaksi terhadap sistem tersebut pada tahun 1998 terjadilah reformasi yang mengganti sitem sentralistik menjadi sistem desentralistik. ${ }^{7}$

Pemerintah pusat melalui kementerian pariwisata (Kabinet Kerja 2015-2019) telah menetapkan bahwa program pengembangan desa wisata menjadi salah satu agenda prioritas. Hal itu dikarenakan nilai penting dan kontribusi pariwisata memiliki dimensi yang luas, tidak hanya secara ekonomi, namun juga secara sosial politik, budaya, kewilayahan dan lingkungan. Secara ekonomi, sektor pariwisata memberikan kontribusi nyata dalam perolehan devisa negara, pendapatan asli daerah dan pendapatan masyarakat yang tercipta dari usaha-usaha kepariwisataan yang dikembangkan.

Perkembangan pembangunan kepariwisataan saat ini mulai menumbuhkan kecenderungan untuk mengolah potensi daerah, terutama desa beserta strategi pemberdayaan yang melibatkan partisipasi masyarakat. Salah satu pengembangan wisata alternatif dalam dunia kepariwisataan adalah desa wisata. Konsep desa wisata merupakan salah satu bentuk pembangunan wilayah pedesaan yang berkelanjutan dalam bidang pariwisata. Pengembangan menjadi desa wisata didasarkan atas potensi dan ciri khas yang dimiliki masing-masing desa, antara lain: flora, fauna, rumah adat, pemandangan alam, iklim, makanan tradisional, kerajinan tangan, seni tradisional, dan sebagainya. Salah satu desa yang konsen dalam pembangunan sebagai desa wisata adalah Desa Kemiren di Kabupaten Banyuwangi. ${ }^{8}$

\footnotetext{
7 Adisasmita Rahardjo, "Pembangunan Pedesaan dan Perkotaan (Makasar: Graha Ilmu, 2006).

8 Wiwin Indiarti dkk.,Pengembangan Program Desa Wisata dan Ekowisata Berbasis Partisipasi Masyarakat di Desa Kemiren Kabupaten Banyuwangi. (Banyuwangi:Laporan Penelitian, 2013), hal.2.
} 
Satu diantara program pengembangan desa adat adalah pelestarian rumah adat masyarakat Osing. Adanya simbolis rumah sebagai peninggalan arsitektur budaya cukup menyita perhatian, dilihat dari bentuk bangunan yang khas dan tradisional membuat setiap wisatawan seakan terasa hidup dizaman tradisionil dan sangat natural. Namun tidak semua rumah adat yang ada di Desa Kemiren masih dipertahankan, melainkan sudah berganti layaknya rumah modern saat ini. Ada penurunan minat dan nilai dalam mempertahankan dan mengembangkan rumah adat ini disebagian masyarakat kemiren, seperti pernyataan kepala adat berikut ini:

“....mengapa sekarang banyak rumah-rumah modern? Dulunya orang-orang Kemiren, terutama para pemuda sempat minder karena dulu sebagai petani tulen akhirnya dikatakan kemiren tertinggal, terlalu kolot, ketinggalan. Akbirnya sebagian yang tidak kuat memegang pluri tadi tergser membuat rumah modern, tapi setelah sekarang Kemiren sudah dijadikan desa adat, akbirnya yang sudah membangun rumah modern jadi menyesal mengapa rumah adatnya dijual. Dan sekarang masyarakat bersepakat untuk mengembalikan rumah adat seperti dulu. Makanya masyarakat Kemiren setujua diperdeskan untuk pelestarian rumah adat, hal itu juga tidak terlepas dari karakter masyarakat Kemiren yang menghargai tentang warisan.

Untuk mengembalikan rumah adat lagi, maka dilakukanlah musrembangdes, yang diawali sosialisasi dari tinggkat RT. Perdes ini baru ditabun 2018, namun pelaksanaan sudah dimulai pada tabun 1995 ketika ditetapkan Desa Kemiren sebagai desa adat...".

Program pelestarian rumah adat Masyarakat Osing bahkan semakin terbantu ketika dana desa bisa dimanfaatkan langsung terutama bagi masyarakat yang tidak mampu. Mereka yang memiliki kesadaran dan tanggung jawab dalam pelestarian budaya namun memiliki keterbatasan finansial juga dapat berperan dan ikut membangun kembali rumah adat yang hampir

\footnotetext{
9 Wawancara dengan Tokoh Adat Kemiren tanggal 4 Desember 2016.
} 
tergantikan oleh model-model bangunan modern saat ini. Seperti yang diungkapkan oleh Kepala Desa Kemiren:

"program pelestarian rumah adat masyarakat Osing pada tahun 2014 menggunakan APBD, namun semenjak tahun 2016 pelestarian rumah adat sudah bisa menggunakan dana desa, terutama didabulukan bagi masyarakat yang kurang mampu. Untuk alokasi dana desa sendiri, per KK nya mendapatkean dana bantuan sebesar lima juta rupiah, dan dibatasi lima KK per tahun”. 10

Itu artinya, program pelestarian tidak hanya diberatkan kepada masyarakat melainkan pemerintah ikut bersama dalam membangun dan mengawal jalannya program tersebut. Walaupun secara finansial besaran bantuan yang diberikan kepada masyarakat sangat jauh dari cukup dan belum ada kepastian bahwa angaran bantuan kepada masyarakat terkusus untuk pembangunan rumah adat akan bertambah dari nominal yang sudah dianggarkan per KK saat ini. Hal itu dikarnakan dana desa juga teralokasikan kepada program-program pembangunan yang lainnya.

Keterbatasan terutama dalam hal finansial, justru memperlihatkan spirit berbudaya yang tinggi dari masyarakat Osing Kemiren. Mereka menyadari untuk membangun rumah adat Osing, setidaknya membutuhkan dana sepuluh hingga lima belas juta rupiah. Diantaranya ibu Sumarni :

" iya saya ikut daftar pembuatan rumah adat Osing, tapi masih ngantri. Sebernarnya bantuan lima juta itu tidak cukup, beli bahan (kayu) saja sudah butub dana besar, belum lagi biaya tukangnya. Ya, karena Desa Kemiren menjadi desa adat, masa rumah adatnya nggak ada, rumah sudah berbentuk modern semua, jadi program ini saya sib setuju juga. Masalah kekurangan dana ya ditambah sendiri lah, jika belum cukup minta yang lain saja dulu yang bikinya”. ${ }^{11}$

\footnotetext{
10 Wawancara dengan Perangkat Desa Kemiren tangaal 29 November 2016.

11 Wawancara dengan Masyarakat Kemiren tanggal 3 Desember 2016.
} 
Dua tahun setelah tahun 2016, informasi dari kepala Desa Kemiren bahwa program rumah adat dari dana desa sudah mencapai sepuluh rumah atau sepuluh KK, dan dalam pendaftaran sudah banyak yang antri untuk membangun rumah adat Osing lewat bantuan dana desa. Artinya, target lima KK per tahun tercapai.

Persoalan bantuan dana untuk membangun rumah adat Osing yang kurang dari cukup, tidak semua warga yang siap untuk membangun rumah adat, namun mereka sangat setuju dengan program tersebut dan menaruh harapan agar bantuannya bisa dilebihkan lagi. Selain itu, ada kendala lain bagi masyarakat untuk ikut membangun kembali rumah adat Osing, seperti lahan untuk membangun yang tidak memadai dan rumah yang sudah terlanjur terbangun (permanen). Seperti rumah ibu Mia yang sehari-hari beliau juga menggunakan halaman rumahnya yang tidak begitu luas untuk berjualan:

"pada dasarnya saya setuju dengan program rumah adat, tapi biayanya belum ada, kalaupun ada dana bantuan, itu masih sangat kurang dan halaman rumah tidak begitu luas. Mungkin saat ini belum ada rencana, lihat kedepannya lah.." 12

Kondisi yang dihadapi ibu Mia di atas adalah satu diantara banyak warga yang juga mengalami kondisi yang sama, selain masalah anggaran yang terbatas, juga terkendala pada lahan rumah dan kondisi rumah yang sudah dibangun permanen. Namun bukan berarti pelestarian rumah adat tidak bisa dilakukan, hal kreatif yang dilakukan perangkat desa adalah pembentukan lokalisasi dimana warga yang tinggal dilokasi tersebut berumahkan rumah adat masyarakat Osing, daerah tersebut berada di daerah Suko Sari Desa Kemiren. Jika kita mengunjungi daerah tersebut, maka sekeliling kita akan terlihat bangunan-bangunan rumah adat Osing. Langkah yang cukup efektif disamping perangkat desa dan masyarakat tetap mengupayakan pengembangan rumah adat lebih masif lagi.

Satu hal yang perlu kita garis bawahi dengan beragamnya penyikapan masyarakat Osing terhadap program pelestarian rumah adat adalah adanya partisipasi masyarakat terhadap program tersebut. Program pembangunan mungkin 
tidak akan ada artinya jika tidak ada partisipasi dari masyarakat pada era otonomi daerah saat ini dimana rencana pembangunan daerah harus disusun berdasarkan potensi yang ada di daerah tersebut. Siapa lagi yang lebih memahami karakteristik daerah kecuali masyarakat yang ada di daerah tersebut. Partisipasi masyarakat merupakan salah satu bentuk pemberdayaan masyarakat social empowering secara nyata dan terarah. Partisipasi atau peran serta masyarakat dalam pembangunan merupakan aktualisasi dari kesediaan dan kemauan masyarakat untuk berkorban dan berkontribusi terhadap implementasi program-program yang dilaksanakan di daerahnya. ${ }^{13}$

\section{Rumah Adat Hingga Homestay}

Dengan program desa wisata, desa adat kemiren tidak hanya memberikan jamuan dalam bentuk pelestarian adat istiadat saja, melainkan juga memberikan dampak terhadap pertumbuhan ekonomi desa tersebut. Banyak multiplier effect yang ditimbulkan dari program desa adat tersebut seingga dapat secara langsung dinikmati oleh masyarakat setempat. Satu diantaranya adalah perkembangan homestay di Desa Kemiren.

Seiring perkembanagan dan didorong oleh kekompakan dan partisipasi masyarakat Desa Kemiren yang massif, keberadaan desa adat kemiren semakin menggema tidak hanya domestik melainkan mancanegara. Hal tersebut juga berdampak terhadap kunjungan wisatawan ke Desa Kemiren yang menjadi cikal bakal dari perkembangan program homestay di Desa Kemiren.

Perkembangan kondisi tersebut membuat pemerintah setempat mengambil langkah yang lebih serius mendorong perkembangan homestay, seperti yang dikemukakan oleh perangkat Desa Kemiren:

" melihat waktu ke waktu peningkatan kunjungan wisatawan yang semakin bertambah, sehingga kebutuhan akan penginapan juga menjadi suatu hal yang harus diperhatikan, maka dari itu, pemerintah memberikan perhatian yang serius untuk pengembangan homestay ini. Tentunya program ini akan melibatkan masyarakat yang sekaligus juga memberikan dampak ekonomi yang positif terhadap masyarakat itu sendiri”. ${ }^{14}$

\footnotetext{
13 Adisasmita Rahardjo, "Pembangunan Pedesaan dan Perkotaan (Makasar: Graha Ilmu, 2006).

14 Wawancara dengan Perangkat Desa Kemiren tangaal 29 November 2016.
} 
Pengembangan homestay di Desa Kemiren juga harus memberikan ciri khas adat istiadat setempat, artinya, homestay yang dibangun merupakan penginapan berbentuk bangunan rumah adat tradisional masyarakat Kemiren. Seperti ungkapan Ketua Adat Desa Kemiren:

"wisatawan datang ke desa ini tentu ingin merasakan dan memiliki pengalaman nuansa adat di desa ini, sebingganya, tempat penginapan juga harus dirancang dalam bentuk rumah adat, karena banyak nilai filosofis dari bangunan adat yang juga menjadi daya tarik bagi wisatawan". ${ }^{15}$

\section{PETA HOMLSTAY}

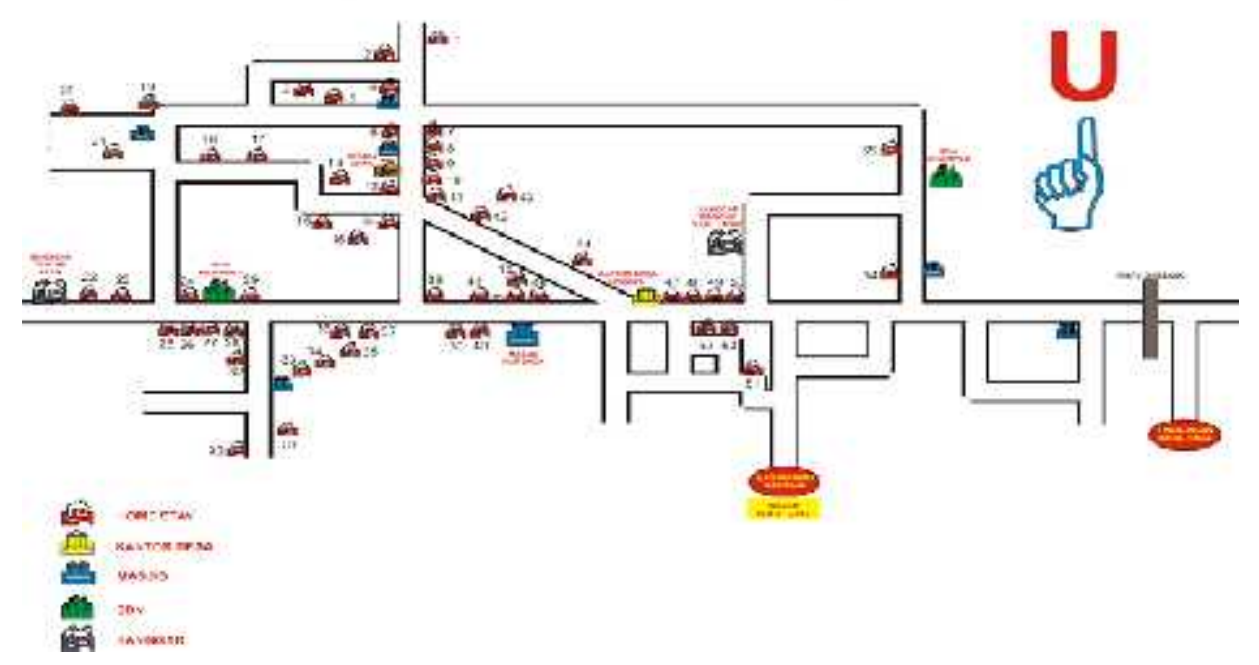

Sumber: Pemerintah Desa Kemiren, 2016

Pengelolaan homestay langsung dilakukan oleh masyarakat. Pemerintah dalam hal ini sebagai fasilitator dalam pengembangan bomestay yang dijalankan, seperti pembinaan kepada masyarakat untuk mempu memanajemen dan tata kelola homestay yang baik.

\section{Penutup}

Program pembangunan pelestarian rumah adat masyarakat Osing bukan sekedar hiasan tradisioanal yang berupa arsitektur budaya, melainkan sebuah manifestasi pembangunan yang dimulai dari lingkup terkecil, yaitu keluarga. Program tersebut muncul tidak hanya keinginan dari pemerintah, melainkan

${ }^{15}$ Wawancara dengan Tokoh Adat Kemiren 4 Desember 2016. 
perwujudan harapan dari masyarakat Kemiren itu sendiri yang ingin mempertahankan nilai-nilai luhur budaya.

Keterlibatan masyarakat dalam proses perencanaan program pelestarian rumah adat masyarakat Osing menggambarkan sebuah proses partisipasi masyarakat dalam sebuah pembangunan. Hal ini sudah seharusnya dipahami setiap pemangku kebijakan dalam merumuskan kebijakan pembangunan terkhusus pembangunan yang berbasis kearifan lokal, karena sejatinya kearifan lokal haruslah dilihat sebagai sumber daya lokal. Mekanisme pengelolaan yang didominasi oleh otoritas negara jelas tidak menjadi jaminan tunggal bagi bekerjanya prinsip-prinsip ketata pemerintahan yang demokratis (democratic governance). Paradigma pembangunan yang bersifat bottom up diharapkan dapat mengurangi persoalan yang muncul ditengah masyarakat yang memang pada dasarnya masyarakatlah yang mengetahui kondisi atau permasalahan yang terjadi di daerahnya.

Efek dari pembangunan yang meletakkan masyarakat tidak hanya sebagai objek pembangunan melainkan juga sebagai subjek dari pembangunan itu sendiri selalu memberikan jawaban atas persoalan yang dihadapi masyarakat, hal itu dibuktikan dengan keterlibatan masyarakat Desa Kemiren dalam proses pembangunan pelestarian rumah adat yang sudah berjalan dari tahun 1995 hingga saat ini. Hakikat pembangunan sejatinya adalah membangun insan itu sendiri. Manusia menjadi faktor utama, baik sebagai subjek maupun objek, sebab pada dasarnya manusia adalah faktor ekologik utama.

Walaupun terlihat sedikit lambat, namun sebagian besar masyarakat Osing menyambut baik program pelestarian rumah adat baik bagi mereka yang sedang pengajuan pembangunan rumah adat maupun yang belum memutuskan untuk membangun rumah adat kembali.

Sebagai evaluasi kedepannya, respon masyarakat terhadap program rumah adat agaknya tidak menjadi satu-satunya indikator penilaian keberhasilan program. Idealnya, jika respon masyarakat sudah menyambut baik program yang direncanakan, sudah seharusnya program tersebut memiliki tingkat ketercapaian 
yang tinggi. Namun sebaliknya, jika realisasi terasa agak lambat, hal itu mengindikasikan dalam proses pelaksanaan terdapat faktor penghambat lain yang harus segera dicarikan solusinya.

Adapun faktor penghambat menurut hemat penulis dalam proses pembangunan rumah adat Osing di Desa Kemiren yang juga merupakan respon dari masyarakat desa adalah dana bantuan yang terlalu sedikit, sehingga ada masyarakat yang belum memutuskan untuk membangun dumah adat. Tentunya rumah adat yang dibangun tidak sekedar terbangun, melainkan juga terukur dari segi kualitasnya. Hal tersebut tentu sudah dimulai dari pemilihan bahan yang bagus sehingga menghasilkan rumah adat yang berkualitas terutama dari segi ketahanan.

Bagi mereka yang sudah terlanjur membangun rumah permanen namun berkeinginan untuk membangun rumah adat tentu akan banyak yang dikorbankan (kerugian materil) dari perombakan. Hal ini juga semestinya menjadi fokus pemerintah untuk membantu mencarikan solusinya karena Perencanaan pembangunan rumah adat Desa Kemiren bukan sekedar wacana, melainkan perencanaan yang sudah melewati proses pengambilan keputusan bersama masyarakat Kemiren yang telah menyambut baik program ini, dan program pembangunan rumah adatpun sudah diperdakan bahkan diperdeskan untuk tingkat desa, artinya baik pemerintah maupun masyarakat sudah siap menyambut konsekuensi yang muncul dikemudian hari.

Besar harapan yang diharapkan dari sebuah program pembangunan pelestarian rumah adat, pembangunan yang sejatinya adalah perubahan kearah yang lebih baik untuk mewujudkan desa wisata di Desa Kemiren. Implikasi semua itu adalah, upaya membangun bersama dan mensejahterakan masyarakat yang ada di Desa Kemiren. 


\section{DAFTAR PUSTAKA}

Adisasmita, Rahardjo. 2006. Pembangunan Pedesaan dan Perkotaan. Makassar: Graha Ilmu

Bintarto.1977.Pengantar Geografi Kota.Yogyakarta:Spring

Brohman, J. 1996. New Direction in Tourism for Third World Development. Annals of Tourism Research. Vol. 23 No. 1, hlm. 48-70

Indiarti, dkk. 2013. Pengembangan Program Desa Wisata dan Ekowisata Berbasis Partisipasi Masyarakat di Desa Kemiren Kabupaten Banyuwangi. Laporan Penelitian. Banyuwangi

Ma'rufi, Isa. 2016. Rumah Adat Using: Pembacaan Dari Sudut Rumah Sehat. Banyuwangi: Ombak

Murdyastuti, Anastasia. 2016. Strategi Kebijakan Pengembangan Kawasan Wisata Using: Studi Desa Kemiren Kecamatan Glagah Kabupaten Banyuwangi. Banyuwangi: Ombak

Soetaryono, Retno. 1985. Pengaruh Tingkat Kemiskinan Terhadap Kerusakan Sos-EkSuatu Studi Kasus di Kec. Jatiujung Kab. Daerah Tingkat II Tanggerang Jakarta. Tesis Pascasarjana Ilmu Lingkungan Ekologi Manusia. Tidak Dipublikasi. Universitas Indonesia. Jakarta

. Undang-Undang Nomor 6 Tahun 2014 Tentang Desa

----------, 2012. Rencana Pembangunan Jangka Menengah Daerah Kabupaten Banyuwangi Tahun 2010-2015. Banyuwangi: Pemerintah Kabupaten Banyuwangi.

Permendagri. No. 114 Tahun 2014, Tentang Pedoman Pembangunan Desa

Wawancara Tokoh adat (04-12-2016)

Wawancara Kepala Desa (29-11-2016)

Wawancara Masyarakat Desa (03-12-2016) 